\title{
The Necessity of Adoption of New National Regulations to Prevent the Pollution of Croatian Coastal Sea by Sewage from Various Vessels
}

\author{
Žarko Koboević, Branka Milošević-Pujo
}

This paper addresses international, Croatian and EU legislation on the prevention of sea water pollution by sewage from vessels. The paper also highlights the disadvantages of international legislation on the protection of coastal sea against pollution by vessel sewage. International legislation is enacted at the global level rather than for each individual coastal sea due to each sea having different exposure to pollution. Either the insufficiently comprehensive national legislation needs to be amended or, more suitably and effectively in the case of the Republic of Croatia, new rules regulating the prevention of coastal sea pollution at the national level and the prevention of negative influence on the marine eco-system, human health and economy established.

\section{KEY WORDS}

$\sim$ Vessel sewage

$\sim$ Sewage treatment plant

$\sim$ Pollution

$\sim$ Legislation

\section{INTRODUCTION}

The pollution of the marine environment is one of the major ecological problems of our time. It has or is likely to have lethal consequences for the living conditions of the marine and underwater flora and fauna. Sea water can be polluted by pathogens, nutrients, chemicals, detergents, pesticides and heavy metals from sewage. The contamination of coastal water may change nutrient levels, abundance, biomass and diversity of organisms, the bioaccumulation of organic and inorganic compounds and the alteration of trophic interaction between species. The issue of sea water pollution and the impact of black water (sewage) on coastal sea have been the subject of research and publication by many authors, including A.M. Owili (2003) Ž. Koboević, Ž. Kurtela (2012). Authors S.E. Henrickson, T. Wong, P. Allen (2001) deal with a variety of human diseases caused by the release of faecal waters into sea. The problem of hypoxia and eutrophication was dealt with by authors V.H. Smith, G.D. Tilman, J.C. Nekola (1999), J.S. Gray, R. Sinu-sun, and Y.Y. Or (2002), S. Hanninen, J. Sassi (2009) and H.Shenping, F. Quangen, Z. Jinpeng (2010). Apart from increased sewage pollution from land sources, the sewage pollution from vessels is also on the rise. The number of cargo ships, cruise ships, yachts and pleasure boats is growing every year. The growing marine traffic increased pollution by sewage from vessels. Vessel sources of sewage include both commercial and recreational vessels. Most commercial vessels have sewage treatment systems designed to remove pollutants from sewage before releasing waste water into the sea. Instead of a sewage treatment system, smaller recreational vessels 
have sewage collection tanks. Papers on the types of tanks for processing black water on ships have been published by M. Bupić and L. Milić (1998.), Dixon, J. Daly and H. Dorr (2002.), Ž. Koboević and Ž. Kurtela (2011). The issue of black water discharge from cruisers in Alaska was addressed by A.Mearns, C.J. Beegle-Krause and L. Loehr, (2005).

A number of international and national regulations have been adopted to prevent sea pollution.

Apart from international regulations on the prevention of marine pollution from vessels, many maritime countries have laid down their own stricter regulations (West, 2004).

\section{RESULTS / REGULATIONS ON SEWAGE WASTE WATER FROM SHIPS}

The issues of waste water discharge, storage and processing onboard, equipment and certificates required to be obtained by vessels are regulated by international and, in some maritime countries, national regulations.

\subsection{International Legislation on the Prevention of Sea Pollution by Sewage from Ships}

The discharge from and holding of sewage (black water) on ships, the equipment and certificates required onboard are all governed by international legislation and national regulations of individual maritime countries. Although not as a rule, highly developed countries frequently lay down national regulations that are more effective or impose more restraints on discharge of ship sewage, and have higher requirements with regard to the purity or quality of treated sewage before its discharge into sea.

The International Convention for the Prevention of Pollution from Ships, 1973/78 (MARPOL 73/78) brought by International Maritime Organization (IMO) is the most important international regulation regulating issues relating to the pollution of sea by vessels. The Convention has a number of Annexes. Annex IV contains provisions regulating the prevention and supervision of marine pollution by sewage waste waters from ships, including by: prohibiting or limiting discharge, certificate issuance and inspections, equipment and supervision of discharge, shore reception facilities. Annex IV to MARPOL is applicable to all ships on international voyages certified to carry more than 12 persons and that are 200 GT and more. Annex IV to MARPOL prohibits the discharge of sewage into sea, except when raw sewage is discharged at a distance greater than 12 nautical miles from the nearest land, or where the ship is discharging comminuted and disinfected sewage processed by an approved system, at a distance greater than 3 nautical miles from the nearest land, or where the ship is discharging sewage using an approved sewage treatment plant; the results of plant effectiveness are laid down in the ship's International Sewage Pollution Prevention Certificate and the effluent must not contain visible floating solids nor cause discoloration of the surrounding water. Discharge of this type is allowed at any location.

Apart from MARPOL, several other international regulations address the issue of pollution by vessel sewage, although not to the extent and with the precision of MARPOL. Those conventions are: The United Nations Convention on Law of the Sea (1982); The Convention for Protection of the Mediterranean Sea against Pollution, adopted in Barcelona in 1976 / Action Plan 1995.; Convention on the Protection of the Marine Environment of the Baltic Sea Area, 1992; Convention for the Protection of the Marine Environment of the North-East Atlantic (OSPAR Convention) 1992.

\subsection{Croatian Legislation on the Prevention of Marine Pollution by Sewage from Ships}

Most Croatian regulations on marine pollution by ships are the result of the adoption of relevant international conventions under the International Maritime Organization, and the implementation of EU rules and regulations. The Republic of Croatia adopted the MARPOL Convention.

In the Republic of Croatia, the issue of protection of sea from sewage discharge has been addressed by a series of acts and regulations, such as: the Maritime Act ${ }^{1}$, Environmental Protection $\mathrm{Act}^{2}$, the Maritime Domain and Seaports $\mathrm{Act}^{3}$, Regulation on the

1. The Maritime Code, OG 181/04, art.64 p.2. "Ship captains and crew members, yacht or boat skippers or crew members are required to comply with international regulations and standards and Croatian regulations on the protection against sea and air pollution by seagoing vessels and pollution caused by the sinking of seagoing vessels in Croatian waters and territorial sea. Rather than proscribing protective measures against marine pollution, the Maritime Code provides for the adoption of more detailed regulations: (art. 64. p.6). "The detailed regulations on the protection of the marine environment from marine facilities and the conduct of pollution investigation shall be brought by the Minister"

2. Environmental Protection Act, OG 110/07, art.24. p.1: "The protection of the sea shall include measures of protection including the marine eco-system and the coastal area as an indivisible whole, the prevention of damage to the marine ecosystem, the prevention of sea pollution from the air, from the mainland, from vessels and other pollutants due to maritime traffic, including pollution caused by dumping from vessels or aircraft with the purpose of sinking or incineration at sea, and cross-border pollution, as well as pollution caused by major accidents and neutralization of their consequences."

3. Maritime Domain and Seaports Act, OG 158/03, art.90 prohibits the release of solid and liquid wastes, oily water, sewage and cargo residues from ships, as well as of all other substances polluting the waters and shores of maritime domain. Mobile, floating and stationary offshore facilities may discharge waste holds, oily water, sewage (black water) and cargo residues from ships in solid and liquid form, while other polluting substances may only be discharged at designated locations in or outside ports equipped with devices for the disposal of such substances. If the harbourmasters find that the unloading of storage tanks might cause pollution of the sea during navigation, the captain of a mobile, floating and stationary offshore facility will be ordered to empty them before leaving the port. 
Conditions and Manner of Maintaining Order in Ports and Other Parts of Internal Sea Waters and the Territorial Sea of the Republic of Croatia ${ }^{4}$. None of the above national acts are as detailed as Annex IV to MARPOL, and neither the measures against pollution by sewage water from ships nor measures against violators have been laid down in as much detail.

\subsection{EU Legislation on the Prevention of Marine Pollution by Sewage from Ships}

All EU member states ratified Annex IV to MARPOL, incorporating stipulations and limitations concerning the discharge of sewage from ships. The European Environment Agency (EEA) is the most important of all EU institutions and bodies for pollution monitoring and control.

The EU has issued a number of documents, initiatives, action plans and strategic instruments for the protection and preservation of the marine environment and especially of the Mediterranean.

There is no single and comprehensive legislation on marine environmental protection in the EU coming even close to the MARPOL convention. Different regulations on pollution prevention addressing various sources of pollution and environmental hazards (e.g. oil pollution, hazardous substances, eutrophication, habitat destruction, municipal waste issue) have been adopted.

The most important pieces of legislation relating to sewage from ships are:

Directive 2002/84/EC of the European Parliament and of the Council of 5 November 2002 amending the Directives on Maritime Safety and the Prevention of Pollution from Ships, instituting the Committee on Safe Seas and the Prevention of Pollution from Ships (COSS), intended to improve the implementation of EU legislation on safety at sea, prevention of pollution from ships and living and working conditions onboard, as well as to accelerate the updating of EU regulations on shipping and facilitate their amendment in the light of developments in international instruments.

4. The provisions of the Regulations apply to all ships, yachts and boats entering Croatian ports and all ports entered by vessels (art.61. p.1.), irrespective of their flag of affiliation, except for war and state ships. In accordance with art.62, p.1, all ports open to the public and special purpose ports are required to compile and implement a Waste and Cargo Residue Receiving and Handling Plan as defined in art.3, p.7. The Ordinance on conditions to be met by ports (waste from vessels is all waste, including sewage and residues, resulting from the use of the ship and referred to in Annexes I, IV and V of MARPOL 73/78, except cargo residues ). When entering a Croatian harbour, the master of a ship, other than a fishing vessel, must present to the harbourmasters and the body that manages the harbour full and accurate data on ship waste and cargo residues. (art.63, p.1). The master of a ship, yacht or boatmaster shall, before leaving the harbour, discharge all shipboard waste into the port's reception facilities. (art.64, p.1).
Directive 2000/59/EC of the European Parliament and of the Council of 27 November 2000 on port reception facilities for ship-generated waste and cargo residues - Commission Declaration, adopted to ensure common ecological standards for private facilities (for liquid and crude waste from ships, or cargo residues) in all ports within the EU. The purpose of this directive is to reduce the quantity of waste (including sewage) discharged.

Directive 2007/71/EC of the European Parliament and the Council on port reception facilities for sewage from ships and cargo residues. It has been in force and effect as of 17 September 2009 and requires ships to advise the port of call on the condition of sewage waste waters onboard. The ships are required to pump out their sewage waters into port reception facilities if the ship cannot discharge sewage waters in compliance with MARPOL or if the ship's capacities are insufficient to keep the sewage waste waters onboard until the next port of call, including sewage collected prior to reaching the next port of call. The purpose of this directive is to reduce the discharge of sewage waters into sea, in particular illegal discharges within $3 \mathrm{~nm}$ from shore. It does not apply to boats and yachts accommodating fewer than 12 passengers and fishing boats.

As far as correlations between international and EU legislation are concerned, it should be noted that the European Community is party to almost all international conventions and agreements dealing with marine environmental protection. The EC may improve the effectiveness of those conventions and agreements by adopting secondary acts (directives or regulations) required to be implemented or directly applied by member states. The adoption of international maritime policies is still within the scope of the International Maritime Organization.

The European Maritime Safety Agency (EMSA) was founded as a special supervisory body of the European Union primarily to monitor the efficiency of the implementation of rules on safety in shipping and prevention of pollution from ships, and the implementation and efficiency of individual measures within the EU. Although EMSA has no legislative function, it is important for the implementation and supervision of maritime policy of EU member states, as well as for monitoring the implementation of the relevant EU regulations into national legislations. (BarićPunda, 2008).

\subsubsection{The Shortcomings of Legislation in the European Union}

The shortcomings of EU legislation on the prevention of sewage pollution from ships based on reviews and experience:

1. Non-existence of a single comprehensive regulation on marine environmental protection against sewage pollution from ships at EU level. ${ }^{5}$

5. EU Directives are focused on individual problems, and lack comprehensive approach to sea pollution such as provided by the MARPOL Convention. 
2. Some maritime regions in the EU (e.g. Baltic Sea, Adriatic Sea and Black Sea) are more exposed and need additional attention and stricter legislation on sewage pollution prevention than is presently applicable at EU level and stipulated in Annex IV to MARPOL.

3. In the Baltic Sea the problem of nutrient input from land and ships is coming into focus of attention. Since pursuant to Annex IV to MARPOL no restrictions are imposed on nitrogen and phosphorus loads from sewage treatment plants, Baltic countries came forward to the international community and IMO with the initiative to adopt new measures and regulations to reduce nutrient input (nitrogen and phosphorus) from shipboard sewage, providing better protection of the ecosystem in the Baltic (IMO, 2009).

4. The Croatian coastline of the Adriatic Sea, as a destination for nautical and recreational tourism for water sports and swimming. The shallowness and semi-enclosed nature make the Adriatic Sea vulnerable to pollution. Untreated waste water from mainly land-based sources and ships further aggravate the situation (Communication from CEP, 2014). Sewage discharge from vessels in internal waters and bays is detrimental to tourists and the tourism sector. This hazard pertains more to vessels such as yachts, pleasure boats and fishing boats, which are exempted from the application of EU level legislation and Annex IV to MARPOL.

\section{DISCUSSION / ISSUES CONCERNING SEWAGE POLLUTION FROM SHIPS NOT COVERED BY THE ADOPTED INTERNATIONAL LEGISLATIVE MEASURES}

1. The limitations in the application of Annex IV to MARPOL depending on ship's gross tonnage are irrelevant, since the sewage onboard is produced by humans (crew and passengers) regardless of a ship's GRT (with the exception of several specialized ships for the transportation of livestock, where the livestock is cargo producing sewage). The sewage load onboard depends directly and exclusively on the number of persons onboard.

2. Ships not engaged in "international navigation" are exempt from the application of Annex IV to MARPOL. Such approach, where national administrations regulate the prevention of sewage pollution from ships flying their national flag and sailing exclusively in their territorial waters, is positive providing national administrations adopt national regulations stricter than MARPOL. As a further disclaimer, Article 11.2 of Annex IV stipulates that the discharge provisions of Annex IV do not apply while vessels remain in waters under state jurisdiction. Consequently if less stringent discharge standards are imposed by the state, ships can capitalize on the weaknesses of state jurisdictions (West, 2004).
3. Annex IV to MARPOL does not apply to ships carrying less than 12 persons, ships navigating in national waters, yachts and vessels carrying less than 12 persons. Annex IV to MARPOL only applies to yachts carrying more than 12 persons onboard. However, yachts are not subject to Port State Control inspections according to Paris Memorandum of Understanding (MOU) or any other similar regional agreements assessing the compliance of equipment, certificates and procedures with conventions such as SOLAS, MARPOL, STCW 78/95, COLREG, ILO 147, Loadline, Tonnage. Yachts to which Annex IV to MARPOL applies are required to have equipment proscribed therein, envisaged to be verified by initial or periodical inspections conducted by the national administration whose flag they fly, but since Port State Control can neither monitor them nor perform inspections it is rather questionable whether the said equipment is in good working order and how and to which extent it is used.

4. Boats (such as sailing boats and motor boats) are exempt due to their gross tonnage and number of persons they are certified to carry, although the length of up to 12 meters and sailing category leave room for some to navigate international waters. Yachts and boats built for voyages longer than one day are equipped with sewage holding tanks of limited capacities which must be emptied. These tanks are mostly emptied into sea, considerably closer to the shore than proscribed by MARPOL, (for untreated sewage $12 \mathrm{~nm}$ or more from nearest land) since MAPROL regulations do not apply to such vessels. On the other hand, the number and density of land-based reception facilities in marinas, wharfs and operational shores is still insufficient to accommodate yachts and boats.

5. The total number of persons onboard yachts and boats during the summer in countries with developed nautical tourism like Croatia, by far exceeds the total number of persons on all merchant ships in the same coastal area. Consequently, sewage from small vessels to which Annex IV to MARPOL does not apply causes significantly greater load and marine pollution than sewage from ships to which the Annex IV to MARPOL applies.

6. The requirements pertaining to the purity grade of discharges from sewage treatment plants refer only to parameters relating to fecal coliform bacteria loads, total suspended solids, biochemical oxygen demand, and $\mathrm{pH}$, but there are still no limitations on nutrient loads such as phosphorus and nitrogen, which could have a significant impact on the eutrophication of closed and shallow seas. Although Annex IV to MARPOL addresses only fecal sewage (black waters), grey waters also have a negative effect on the sea since nutrient input may lead to eutrophication. 7. There are still some maritime regions which are more susceptible to pollution than other seas (e.g. the Baltic Sea, the Adriatic Sea, and the Black Sea) (Steckbauer et al., 2011). MARPOL defines certain maritime areas as "special areas" in 
which, due to technical reasons relating to their oceanographic and ecological condition and maritime traffic, the adoption of special mandatory methods for the prevention of sea pollution is required (IMO, 2009). Under the Convention, these special areas are afforded higher level of protection than other maritime areas. Only the Baltic Sea is considered a special area under Annex IV to MARPOL (Article 13.2 of the revised Annex IV to MARPOL adopted by the MEPC.200(62) resolution, which entered into force on 1 January 2013). Unlike the Baltic Sea, the exposure of the Adriatic Sea to sewage discharge from ships is still insufficient to cause eutrophication. Nevertheless, sewage discharge from yachts and boats in "internal waters" and bays of the Croatian Adriatic coastline, as a nautical and recreational tourism, water sports and swimming destination, may have impact on the economy and human health. (Koboević and Kurtela, 2012).

\section{DISCUSSION / SUGGESTIONS FOR IMPROVEMENTS IN THE PROTECTION OF THE SEA FROM SHIPBOARD SEWAGE POLLUTION IN THE REPUBLIC OF CROATIA}

The internal waters and bays are more exposed to sewage pollution from ships, yachts and boats to which Annex IV to MARPOL does not apply. The risk of the very narrow coastline of the coastal sea becoming polluted by black wastewater from vessels mostly comes from smaller vessels in national navigation, yachts and boats to which international regulations do not apply (Annex IV to MARPOL). Therefore, the problem cannot be resolved by amending existing international regulations.

The issue of the discharge of black waste water, along with other waste from recreational vessels is recognized and listed in the Strategy for Maritime Development and Integral Maritime Policy of the Republic of Croatia 2014-2020 from July 2014 . $^{6}$

The solution might be the amendment of existing national regulations which, in contrast to the previously adopted international regulations (Annex IV to MARPOL and EU Directive), would also apply to vessels which are not covered by such international legislation and specifically regulate the discharge of black waste waters from vessels in national traffic, such as fishing boats, ro-ro passenger ships (ferries), boats and yachts, as well as mega-yachts and boats in international traffic.

6. "The Strategy for Maritime Development and Integral Maritime Policy of the Republic of Croatia 2014-2020", from July 2014, Chapter 3.2.: "The recent significant pressure on the marine environment and the deterioration of its quality come not only from classical shipping, but can also be attributed to the increased development of nautical tourism, which has negative effects, manifested especially in the quantities of waste and sewage water, necessitating the adoption of technical, technological and organizational measures for the establishment of an effective ship waste management system, and improvement of conditions for efficient ship and marine waste management."
National legislation similar to that of some other developed countries like the USA ${ }^{7}$ and Australia will have to be adopted. ${ }^{8}$

Bearing the above in mind, the adoption of a new regulation on the protection against marine pollution by black waters from ships, yachts and boats sailing in internal sea waters and in the territorial sea is proposed.

\section{Explanation of the basis for the adoption of such regulations:}

Although several Croatian regulations (the Maritime Code, the Maritime Domain and Seaports Act, Regulations on the Conditions and Manner of Maintaining Order in Ports and in Other Parts of Internal Sea Waters and the Territorial Sea of the Republic of Croatia) make mention of marine pollution by ships, vessels, yachts and boats, no measures ensuring protection against pollution are proscribed. Since regulations on the protection of the marine environment against pollution by black waters from yachts and boats in inland waters and territorial sea do not exist, pursuant to art.64, p.2 and art.64, p.6 of the Maritime Code, which reads "The detailed regulations on the protection of the marine environment against marine facilities and the conduct of pollution investigation must be brought by the Minister", there is basis for the adoption of a new regulation on the protection against marine pollution by black waters from ships, yachts and boats sailing in internal sea waters and in the territorial sea.

\section{Explanation of the basic issues to be regulated by the regulation and the consequences of its adoption:}

The proposed regulation might regulate the protection of the sea against pollution by black water from vessels in internal sea waters and territorial sea in compliance with Annex IV MARPOL Convention standards, and apply to all ships, yachts and boats, regardless of their flag of affiliation. The conditions under which yachts and boats would be permitted to discharge black water during navigation in the territorial sea and inland waters are proposed.

7. One of the options would be the "No Discharge Zone", like in the USA. The discharge of sewage from ships would be absolutely prohibited in these zones regardless of the ship's category, gross tonnage and number of persons onboard. Sewage would be stored onboard until the ship is at sufficient distance from the nearest land (proscribed) or reaches land-based sewage receipt facilities, which should be built in all ports, marinas, operational shores etc. "No Discharge Zones" must be designated by national legislation.

8. An example of such regulation is the Australian regulation, which apart from Annex IV to MARPOL, contains a very detailed regulation pertaining to smaller vessels in national waters, national park areas and the narrowest coastal strip, where discharge of sewage is absolutely prohibited in the vicinity of the land or people, and allowed only at a set distance from land or in inland-based reception facilities for shipboard sewage. See AMSA (2012) and Australian Legislation (2008) - Transport Operations (Marine Pollution) Regulation. 
The adoption of the proposed regulation would facilitate better protection of the narrow coastal sea area against black water pollution and consequently of beaches and tourism as the most important economic sector in the Republic of Croatia. The regulation would contribute to sustainable development and the promotion of the highest standards of ecological protection of the sea.

The most important provisions of the proposed regulation on the prevention of pollution by black waters from vessels, yachts and boats sailing in internal sea waters and the territorial sea would be as follows:

1. The regulation is intended to proscribe protective measures against pollution by black water, which would apply to all ships, yachts and boats sailing or located in the internal sea waters and the territorial sea of the Republic of Croatia.

2. All ships, regardless of their flag of affiliation, should be prohibited from discharging black water into the sea, contrary to the provisions of Rule 11, item 1 and item 3 of Annex IV to the MARPOL Convention, while sailing or being located in the internal sea waters and in the territorial sea.

Explanation: This provision echoes the already accepted provision of Annex IV to the MARPOL Convention which applies to all vessels in international navigation, providing that the new regulation would extend the scope of application to all ships in national navigation.

3. All yachts and all boats, regardless of their flag of affiliation, should be prohibited from discharging black water into the sea, while sailing or being located in the internal sea waters and in the territorial sea, except when:

- a yacht or boat discharges black water that has not been macerated and disinfected at a distance greater than 12 nautical miles from the nearest land, provided that during the discharging the yacht or boat sails at the speed of at least 4 knots;

- a yacht or a boat discharges black water that has been macerated and disinfected at a distances greater than 3 nautical miles from the nearest land, provided that during the discharging the yacht or boat sails at the speed of at least 4 knots;

- a yacht or boat is equipped with an approved sewage treatment plant that meets the requirements of Article 9.1.1. of Annex IV to the MARPOL Convention, for which documents were issued by the competent national authority. The effluent from this device must not contain visible floating particles and must not change the color of the surrounding water.

Explanation: limitations on black water discharge applicable to yachts and boats comply with the provisions of Annex IV to the MARPOL Convention, and thus equate ships, yachts and boats in this matter. Since the harmful effect of black water discharge from yachts and boats is no lesser than the harmful effect of black water from ships, there is no reason for the yachts and boats to be in a privileged position.

In addition, the United Nations Convention on the Law of the Sea (1982) recommends that States adopt national regulations for the prevention, reduction and monitoring of marine pollution from ships, which should not be less effective than the generally accepted international rules and standards adopted by the relevant international organization.

\section{Explanation for the implementation of the proposed regulations and port reception facilities}

The implementation of the regulation on the protection against marine pollution by black waters from ships, yachts and boats sailing in internal sea waters and in the territorial sea, will impel yachts and boats to discharge black water at the designated distance from the coast (minimum $3 \mathrm{~nm}$ ), where it will affect neither human health, sea biodiversity nor the aesthetic appearance of the sea.

Alternatively, yachts and boats may empty their black water collection tanks into port reception facilities (pump-out stations).

Port reception facilities are already available in Croatian international harbors. Croatia has a comprehensive and modern legal and institutional framework for port reception facilities, compliant with the MARPOL Convention and EU Directive 2000/59, regulating port reception facilities and the collection of waste generated by ships at its ports. Port reception facility system refers to the installation of receiving devices and shipgenerated waste management plants in ports.

The disposal of black water and garbage from ships is carried out by waste disposal utility companies with concluded concession contracts with port authorities. Local ports and port sports and recreational facilities (marinas) in Croatia are rarely equipped with stationary pump-out facilities. The service is provided by mobile units, i.e. dedicated trucks with a collecting sewage tank. The collected black waters from boats are discharged into the local sewage system.

The cost recovery system currently being applied in Croatia is the direct billing system, e.g. ships or their agents pay the waste collection and garbage collection services directly to service providers. Port authorities determine and publish tariffs for such services.

Given the results of the research on the general behavior of boat and yacht owners and/or operators regarding the discharge of black water into the sea and general human behavior, the impression is that the system of the direct billing of costs of black water disposal into receiving stations is not very stimulating for owners/boat operators and should therefore be changed. Research on responsible environmental behavior of boat and 
yacht owners and/or operators in Maryland, USA, shows that although they are familiar with the regulations on the prohibition of the discharge of black waste waters along the coast (more than three miles from the coast), many owners/operators of boats and yachts discharge untreated black water into the sea near the shore. Many factors and/or circumstances (pressures) are involved in this behavior. The most common are: the inability to sail off the coast where dumping is permitted (three miles or so), lack of local reception facilities for black water, the inaccessibility of receiving stations, lack of adequate legal constraints, lack of knowledge of the hazards posed by black waters to public health and marine organisms, lack of responsible ecological awareness, etc. In addition, the volume of tanks for black water on smaller vessels is very limited, and given normal use, they quickly fill up and require frequent emptying. Moreover, in reply to the question: "What would induce you to use black wastewater treatment stations more frequently?" $61 \%$ of ship owners opted for better working hours, $51 \%$ for lower cost of reception facilities, $42 \%$ for the availability of mobile stations for reception, $20 \%$ for shorter standby time and shorter line at the receiving station, $42 \%$ for better designed reception facilities which would encourage greater use. Survey results indicate that more than half of the respondents mentioned the costs of using black water reception facilities, which is understandable given the general human tendency not to pay for the things the payment of which can be evaded.

Therefore, the possibility of introduction of a vessel waste and black water collection billing system, which would provide for the inclusion of waste disposal costs in the price of the stay or berth per day for each vessel should be considered. Concessionaires who collect waste should be obliged to visit each boat once a day to collect black water and charge their services to the organization that collects the port fee (including the waste collection fee).

Another option would be for the entire Croatian coastal sea to be designated as a "No Discharge Zone". For such a measure to be efficient an appropriate number of land-based reception facilities throughout the "No Discharge Zone" is required.

\section{CONCLUSION}

The causes of inefficient sea protection and preservation are numerous and complex. Apart from economic, political and other differences between countries and the problem of limited finances, there are still low political priority and low public awareness of environmental issues in certain countries. The above discussion on international legislation regulating the prevention of marine pollution by sewage from ships indicates that the adopted measures do not adequately protect coastal seas from shipboard sewage pollution. Coastal sea is still at risk due to the number of operating smaller vessels to which international regulations do not apply. Consequently, better protection of coastal sea cannot be sought at the level of international regulations, but in the development and improvement of national legislation functioning as an addition and amendment to the adopted international regulations.

National regulations should address specific pollution problems which are not covered by international regulations or improve the efficiency of adopted measures which currently do not provide quality protection against shipboard sewage pollution. There are countries that have dealt with the similar problem of sewage pollution from ships. They have found solutions in the adoption of their national regulations or in an even more efficient combination of international and national regulations. Such positive experiences and solutions might simply be adjusted to the specific features of the Adriatic Sea and Croatian legislation.

There is no doubt that much better results in the area of protection of the coastal sea from shipboard sewage pollution could be achieved by the parallel application of international regulations pertaining to ships in international waters and national regulations pertaining to ships and smaller vessels in national waters.

\section{REFERENCES}

AMSA, (2012), Summary of Discharge Standards for Ships and Smaller Vessels Operating in Australian Waters: MARPOL and local requirements, AMSA, Australian Government, available at: http://www.amsa.gov.au/Marine_Environment Protection/Protection_of_Pollution_from_Ships/Discharge_Standards.asp, [accessed 15 February 2018.].

Australian Legislation, (2008), Transport Operations (Marine Pollution) Regulation 2008 Subordinate Legislation 2008 No. 254 made under the Transport Operations (Marine Pollution) Act 1995 Volume 2, Queensland Government, available at: http:// www.legislation.qld.gov.au/LEGISLTN/SLS/2008/08SL254V2.pdf, [accessed 1 March 2018.].

Barić-Punda, V., (2008), The Role of the European Union in Protection and Preservation of the Mediterranean With Review of Some Legal and Strategic Documentation, Faculty of Law in Split Alamanac, 2008(4), pp. 761 - 788.

Bupić, M., Milić, L., (1998), Ship's Sewage Treatment Plant With Reference to Venting and Clarification Procedures, Naše More, 45 (3-4, 5-6)

Commission Directive 2007/71/EC of 13th December 2007 amending Annex II of Directive 2000/59/EC of the European Parliament and the Council on port reception facilities for ship-generated waste and cargo residues, available at: http://eur-ex. europa.eu/LexUriServ/LexUriServ.do?uri=CELEX:32007L0071:EN:NOT [accessed 15 February 2018.].

Communication from the Commission to the European Parliament, the Council, European Economic and Social Committee and the Committee of the Regions concerning the European Union Strategy for the Adriatic and Ionian Region, COM/2014/0357 final, available at: http://eur-lex.europa.eu/legal-content/EN/ TXT/?uri=COM:2014:357:FIN [accessed 1 March 2018.]. 
Directive 2000/59/EC of the European Parliament and of the Council of 27th November 2000 on port reception facilities for ship-generated waste and cargo residues - Commission Declaration, available at: http://eurlex.europa.eu/LexUriServ/ LexUriServ.do?uri=CELEX:32000L0059:EN:HTML [accessed 1 March 2018.].

Hanninen, S. and Sassi, J., (2009), Estimated Nutrient Load From Waste Waters Originating From Ships in the Baltic Area - updated 2009, Research report VTT-R-07396-08, VTT Technical Research Center of Finland

IMO, (2009), IMO Proposal to amend MARPOL 73/78 Annex IV to include the possibility to establish special zones for the prevention of pollution by sewage and to designate the Baltic Sea as such Special zone, Consideration and adoption of amendments to mandatory instruments, available at: http://www.helcom.fi/stc/ files/shipping/Proposal \%20to \%20amend \%20MARPOL \%20Annex \%20IV.pdf

IMO, (2011), Annex 12, Resolution MEPC.200(62), adopted on 15 July 2011, Amendments to the Annex of the Protocol of 1978 Relating to the International Convention for the Prevention of Pollution from Ships, 1973 (Special Area Provisions and the Designation of the Baltic Sea as a Special Area under Annex IV to MARPOL), available at: http://www.imo.org/blast/blastDataHelper.asp?data_ id $=30759 \&$ filename $=200 \% 2862 \% 29 . p d f$

IMO, (2006), IMO Resolution MPC.157 (55) Recommendation on Standards for the Rate of Discharge of Untreated Sewage from Ships, adopted on 13th October 2006, available at: http://www.imo.org/includes/blastDataOnly.asp/data_id \%3D16315/157\%2855 \%29.pdf

IMO, (2006), IMO Resolution MEPC.159 (55) Revised Guidelines on Implementation of Effluent Standards and Performance Tests for Sewage Treatment Plants, adopted on 13th October 2006, available at: http://www.imo.org/includes/blastDataOnly. asp/data_id \%3D16317/159\%2855 \%29.pdf

Koboević, Ž., Komadina, P. and Kurtela Ž., (2011), Protection of the Seas from Pollution by Vessel's Sewage with Reference to Legal Regulations, Promet-Traffic \& Transportation 23 (5), pp. 377-387., available at: https://doi.org/10.7307/ptt.v23i5.156

Koboević Ž., and Kurtela Ž., (2011), Comparison of Marine Sewage Treatment Systems, 14th International Conference on transport science ICTS 2011, Portorož, Slovenia, May 27
Koboević Ž., and Kurtela Ž., (2012), Impact of Untreated Sewage discharge on Marine Environment, 15th International Conference on transport science ICTS 2012, Portorož. Slovenia, May 28

Milošević B., (1999), Marine Environments and their Protection, (in Croatian), Polytechnic of Dubrovnik

Milošević-Pujo B., (2006), Pomorsko pravo (Odabrane teme po STCW konvenciji), Dubrovnik

Milošević-Pujo B., Pertinović R., (2008), Pomorsko pravo za jahte i brodice, Split

Narodne Novine, (2009), Croatian Register, Rules for Statutory Certification of Seagoing Vessels Part 22 - Prevention from Pollution (published in Croatian), NN 2009(65)

Narodne Novine, (1998), Convention on Protection of the Marine Environment and Mediterranean Coastal Zone (Barcelona, 1995) (published in Croatian), NN 1998(17)

Narodne Novine, (2005), MARPOL Convention (published in Croatian), NN 1992(1) and 2005(4)

Regulation (EC), (2002), No 2099/2002 of the European Parliament and of the Council of 5 November 2002 establishing a Committee on Safe Seas and the Prevention of Pollution from Ships (COSS) and amending the Regulations on maritime safety and the prevention of pollution from ships, available at: http://eurlex.europa.eu/ LexUriServ/LexUriServ.do?uri=OJ:L:2002:324:0001:0005:EN:PDF

Steckbauer A., Duarte C.M., Carnstensen J. and Vaquer-Sunyer R., (2011), Ecosystem impacts of hypoxia: thresholds of hypoxia and pathways to recovery, Environmental Research Letters 6(2), available at:

https://doi.org/10.1088/1748-9326/6/2/025003

USCG, (2009), Compliance with International Sewage Regulations in Annex IV to MARPOL 73/78, US Coast Guard, Navigation and Vessel Inspection Circular No. 1-09, available at: http://www.uscg.mil/hq/cg5/nvic/pdf/2009/NVIC_1-09.pdf

West A., (2004), Marine Pollution from Vessel Sewage in Queensland, Australian and New Zealand Maritime Law Journal 18, pp. 126-151. 